\title{
IDENTIFICATION OF FETAL DNA AND CELLS IN SKIN LESIONS FROM WOMEN WITH SYSTEMIC SCLEROSIS
}

\author{
Carol M. Artlett, Ph.D., J. Bruce Smith, M.D., and Sergio A. Jimenez, M.D.
}

\begin{abstract}
Background Systemic sclerosis is a disease of unknown origin which often occurs in women after their childbearing years. It has many clinical and histopathological similarities to chronic graft-versushost disease. Recent studies indicate that fetal stem cells can survive in the maternal circulation for many years post partum. This finding suggests that fetal cells persisting in the maternal circulation or tissues could be involved in the pathogenesis of systemic sclerosis by initiating a graft-versus-host reaction.

Methods We used the polymerase chain reaction (PCR) to identify Y-chromosome sequences in DNA extracted from peripheral-blood cells and skin lesions from women with systemic sclerosis of recent onset. To confirm the PCR findings, we used fluorescence in situ hybridization of peripheral-blood cells and cells within chronic inflammatory-cell infiltrates in biopsy specimens of affected skin.

Results Y-chromosome sequences were found in DNA from peripheral-blood cells in 32 of 69 women with systemic sclerosis (46 percent), as compared with 1 of 25 normal women (4 percent, $\mathrm{P}<0.001$ ), and in $\mathrm{T}$ lymphocytes from 3 women with systemic sclerosis who had male offspring. Furthermore, Y-chromosome sequences were identified in skinbiopsy specimens from 11 of 19 women with systemic sclerosis (58 percent); 9 of the 11 were known to have carried male fetuses. Nucleated cells containing $Y$ chromosomes were detected by fluorescence in situ hybridization in paraffin-embedded sections of skin lesions from all seven women we tested whose skin-biopsy specimens contained Y-chromosome sequences.
\end{abstract}

Conclusions Fetal antimaternal graft-versus-host reactions may be involved in the pathogenesis of systemic sclerosis in some women. (N Engl J Med 1998;338:1186-91.)

(C)1998, Massachusetts Medical Society.

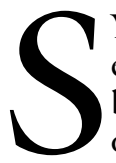
YSTEMIC sclerosis is a connective-tissue disease of unknown origin that is characterized by cutaneous and visceral fibrosis; production of autoantibodies, including anticentromere and anti-topoisomerase antibodies; and prominent microvascular changes, with endothelial-cell damage and proliferation of subendothelial connective tissue. The highest incidence of systemic sclerosis occurs between 45 and 55 years of age, $, 1,2$ and it is three to eight times as frequent in women as in men..$^{3-5}$ These observations suggest that pregnancy-related events are involved in its pathogenesis, although epidemiologic studies to evaluate to what extent a pre- vious pregnancy is a risk factor for systemic sclerosis have not been performed.

Systemic sclerosis has clinical features similar to those of graft-versus-host disease, ${ }^{6}$ and it has therefore been postulated that it may be a form of that disease. ${ }^{7-11}$ Skin, lung, and esophageal involvement is prominent in both diseases, $, 10,12$ and both are characterized by lymphocytic infiltration of affected tissues, ${ }^{13-15}$ up-regulation of inflammatory cytokines, ${ }^{16-18}$ and fibrosis of the dermis and visceral organs. ${ }^{19}$ Furthermore, in a recent study, the systemic sclerosisspecific autoantibodies $\mathrm{Scl}-70$ and $\mathrm{Pm}-\mathrm{Scl}$ were found in 6 of 19 patients ( 32 percent) with chronic graftversus-host disease who presented with clinical symptoms and findings similar to those of diffuse systemic sclerosis. ${ }^{20}$ Graft-versus-host disease due to the transplacental transfer of maternal $\mathrm{T}$ cells has been reported in infants, ${ }^{21}$ and erythema toxicum neonatorum has been postulated to be a mild, self-limited form of graft-versus-host disease caused by maternal cells in newborns. ${ }^{22}$

During pregnancy, fetal and maternal cells of various types are transferred between the mother and the fetus, predominantly from the fetus to the mother. ${ }^{23}$ Fetal erythrocytes and leukocytes can be found in the peripheral blood of up to 25 percent of pregnant women during the first trimester ${ }^{24}$ and 40 to 70 percent of women by the third trimester. ${ }^{25}$ Fetal stem cells engrafted in the maternal lymphoid organs or bone marrow may help to maintain tolerance to the semiallogeneic fetoplacental graft, and fetal hematopoietic stem cells have been detected in the circulation of women up to 27 years post partum. ${ }^{26}$ It has been suggested that a microchimerism established by fetal cells together with activation of such cells may induce a chronic graft-versus-host disease manifesting as systemic sclerosis. ${ }^{27-29}$

To test this hypothesis, it was first necessary to demonstrate the presence of fetal nucleated cells in affected tissues from women with systemic sclerosis who had previously been pregnant. For this purpose, we examined the male-specific Y-chromosome sequence DYZl as a marker for fetal cells in affected tissues from women with systemic sclerosis. We de-

From the Department of Medicine, Division of Rheumatology, Jefferson Medical College, Thomas Jefferson University, Philadelphia. Address reprint requests to Dr. Jimenez at the Department of Medicine, Division of Rheumatology, Thomas Jefferson University, Rm. 509, Bluemle Life Sciences Bldg., 233 S. 10th St., Philadelphia, PA 19107-5541. 
scribe the presence of the Y-chromosome-specific sequence in DNA extracted from the peripheral blood and affected skin of women with systemic sclerosis. These observations provide support for the hypothesis that a fetal antimaternal graft-versus-host reaction may be an immunopathogenic mechanism in the development of systemic sclerosis in some women.

\section{METHODS}

\section{Subjects}

We extracted DNA from peripheral-blood cells of 69 women with systemic sclerosis and 25 normal women by a procedure involving sodium chloride-ethanol precipitation. ${ }^{30}$ Two of the women with systemic sclerosis had had male children, but the pregnancy histories of the remainder of these women and of the 25 normal women were not known. DNA was also extracted from biopsy specimens of active skin lesions from 19 women who had had systemic sclerosis for 18 months or less, and from peripheral-blood cells of 2 of these women. Sixteen of the 19 women with systemic sclerosis had been pregnant before the onset of disease.

As controls, DNA was extracted from skin-biopsy specimens of 7 women with osteoarthritis and 61 female relatives of these 7 women (who were subjects of another study), 29 percent of whom were known to have had male children and 15 percent of whom were known to have had female children $(31$ percent were nulliparous, but the pregnancy histories of the remainder were not known). We also extracted DNA from biopsy specimens of skin and fascia from active lesions of nine women with eosinophilia myalgia syndrome and two women with eosinophilic fasciitis and from a muscle-biopsy specimen from one woman with polymyositis. One of these 12 women had had multiple pregnancies; the histories of the remainder were not known.

The diagnosis of systemic sclerosis was established according to the criteria of the American College of Rheumatology (previously known as the American Rheumatism Association). ${ }^{31}$ All the women attended the Scleroderma Center of Thomas Jefferson University Hospital between 1987 and 1997. The mean age of the women with systemic sclerosis was 53 years (range, 20 to 86), and the mean age of the normal subjects and control patients was 49 years (range, 25 to 75 ). The study protocol was approved by the institutional review board of Thomas Jefferson University, and informed consent was obtained from all subjects.

\section{Polymerase-Chain-Reaction Analysis for Y-Chromosome-Positive Cells}

A specific Y-chromosome sequence was detected by amplifying DNA in a nested polymerase chain reaction (PCR) with primers Yl-1 and Y1-2, as described previously. ${ }^{32}$ The first amplification was done with primers Y1-1 and Y1-2, and the second amplification was done with primers designed by our laboratory; they were Yl-3, which has the sequence 5'CAGGCCTGTCCATTACACTACA3', and Yl-4, which has the sequence 5'GAATGGGAACGAATGGAGTGAA3'. Sixty amplification cycles were performed in the presence of 10 percent dimethyl sulfoxide and $10 \mathrm{U}$ of Taq polymerase (Perkin-Elmer Cetus, Foster City, Calif.) in a Rapidcycler PCR thermocycler (Idaho Technologies, Idaho Falls, Idaho). The conditions for amplification were denaturation at $94^{\circ} \mathrm{C}$ (five seconds), annealing at $60^{\circ} \mathrm{C}$ (two seconds), and extension at $72^{\circ} \mathrm{C}$ (five seconds) for 20 cycles, followed by 40 cycles of denaturation at $94^{\circ} \mathrm{C}$ (five seconds), annealing at $54^{\circ} \mathrm{C}$ (two seconds), and extension at $72^{\circ} \mathrm{C}$ (five seconds). All PCR analyses contained a blank (without DNA) for a negative control and a known positive sample for the $\mathrm{Y}$ sequence (male DNA). The resulting 148-bp Y-chromosome-specific fragment was identified by ethidium bromide staining after electrophoresis on a 1.5 percent agarose gel.

\section{Sequence Analysis of the PCR-Amplified Product}

The 148-bp PCR product was sequenced to confirm its identity. The fragment was cloned into the TA cloning vector (Clontech, Palo Alto, Calif.) and sequenced with M13 forward and reverse primers. The sequence results were analyzed with the program GenBank Search.

\section{Fluorescence in Situ Hybridization of Peripheral-Blood Cells}

Peripheral-blood cells from three women with systemic sclerosis who had carried male fetuses, one woman with systemic sclerosis who had never been pregnant, and two normal women were separated by a magnetic cell-separation device (Immunicon, Huntington Valley, Pa.). Peripheral-blood mononuclear cells were isolated by Ficoll-Hypaque centrifugation (Pharmacia Biotech, Piscataway, N.J.) and washed twice in phosphate-buffered saline containing 0.1 percent bovine serum albumin. The cells were resuspended in $0.85 \mathrm{ml}$ of solution, and $20 \mu \mathrm{l}(0.25 \mu \mathrm{g}$ per milliliter) of mouse monoclonal antibodies directed either against CD3 (T cells) or against CD14 (monocytes) and CD45 (leukocytes) was added. The reaction mixtures were incubated at room temperature for 25 minutes, and $0.85 \mathrm{ml}$ of a freshly prepared 1:20 dilution of goat antimouse antibodies conjugated to magnetic colloidal particles (Immunicon) was added. After a further 10 minutes of incubation, the cells were washed in $10 \mathrm{ml}$ of phosphate-buffered saline, centrifuged, and resuspended in $1.7 \mathrm{ml}$ of phosphate-buffered saline.

The resuspended cells were transferred to a collection vessel and inserted into a magnetic field for 15 minutes at room temperature. A new collection vessel containing $1.7 \mathrm{ml}$ of phosphatebuffered saline was then raised onto the collecting loops, and the cells were recovered by agitating the collection device for one to two minutes. Cells recovered from the wire loops and those not adhering to the loops were suspended in $50 \mu \mathrm{l}$ of fresh 3:1 methanol-acetic acid solution for fixation. Between 30 and $40 \mu \mathrm{l}$ of the cell suspension was then pipetted onto clean glass slides and air-dried. The number of cells on each slide was approximately 5000 per square centimeter. The X- and Y-chromosome probes were pipetted onto the slides and incubated as described below for the tissue sections. Signals were visualized with a Leitz Orthoplan II fluorescence microscope with a triple-bandpass filter (Leitz, Rockleigh, N.J.). In each subject, 3000 nuclei were examined, and the number of signals for each probe was recorded. Image capture and recording were performed with the Oncor Image Analysis System (Oncor, Gaithersburg, Md.).

\section{Fluorescence in Situ Hybridization of Paraffin-Embedded Skin-Biopsy Specimens}

Sections were cut from paraffin-embedded skin-biopsy specimens from seven women with systemic sclerosis in whom PCR amplification of DNA extracted from skin lesions yielded the 148-bp fragment. The sections were analyzed for the presence of Y-chromosome-positive cells by fluorescence in situ hybridization. Skin-biopsy specimens from 10 women without systemic sclerosis were examined simultaneously. The sections were deparaffinized in xylene for 10 minutes and washed twice for 5 minutes each in 100 percent ethanol. The sections were treated with 0.1 percent pronase at $45^{\circ} \mathrm{C}$ for 10 minutes and then with $0.25 \mathrm{mg}$ of proteinase $\mathrm{K}$ per milliliter at $45^{\circ} \mathrm{C}$ for 30 minutes, after which they were dehydrated in 70,80 , and 95 percent ethanol for 1 minute each. The X- and Y-chromosome probes (Oncor) were diluted 1:10 with Hybrisol VI (Oncor), and $10 \mu \mathrm{l}$ was pipetted onto each section and covered with plastic film. The slides were heated at $70^{\circ} \mathrm{C}$ for five minutes, incubated overnight at $37^{\circ} \mathrm{C}$, washed at $70^{\circ} \mathrm{C}$ in $2 \times$ saline sodium citrate $(1 \times$ saline sodium citrate is $0.15 \mathrm{M}$ sodium chloride and $0.015 \mathrm{M}$ sodium citrate) for five minutes, counterstained with $0.1 \mu \mathrm{g}$ of 4,6-diamidino2 -phenylindole in an antifade solution (Oncor), and viewed with an epi-fluorescence microscope (Zeiss, Thornwood, N.Y.) with a 
triple-bandpass filter. The nuclei in the paraffin-embedded skin biopsy specimens were examined by fluorescence in situ hybridization for both the $\mathrm{X}$ chromosome (fluorescein) and the Y chromosome (Texas red). The results from the control and test groups were compared by the chi-square test with Yates' correction.

\section{RESULTS}

\section{PCR Analyses of Peripheral-Blood and Skin DNA}

The Y-chromosome sequence was amplified from DNA extracted from peripheral-blood cells in 32 of the 69 women with systemic sclerosis (46 percent), but in only 1 of the 25 normal women ( 4 percent, $\mathrm{P}<0.001)$. Cloning and sequencing confirmed the identity of the Y-chromosome-specific product amplified from the DNA samples of the women with systemic sclerosis. The amplified product had 98 percent sequence identity with the DYZl sequence unique to the $\mathrm{Y}$ chromosome, indicating that it was a male-chromosome sequence and not an unrelated gene.

Y-chromosome-specific DNA was detected in skin lesions of 11 of the 19 women in whom it was sought ( 58 percent), but in none of the skin-biopsy specimens of the 68 women with osteoarthritis or their relatives $(\mathrm{P}<0.001)$. The results of a representative experiment are shown in Figure 1. A prominent band represents the 148-bp product amplified from Y-chromosome DNA in samples from three women with systemic sclerosis (lanes 5, 8, and 10; arrow) and a similar product in DNA from skinbiopsy specimens from two normal men (lanes 3 and $9)$. The faster-migrating band seen in all lanes represents primer-dimer formation. The sample obtained from Patient 4 (lane 8 ) had such a high concentration of male DNA that the PCR results are those expected for a male pattern. No Y-chromosome-specific sequence material was detected in the DNA extracted from the active lesions of the women with the eosinophilia myalgia syndrome, eosinophilic fasciitis, or polymyositis.

\section{Fluorescence in Situ Hybridization of Peripheral-Blood Cells}

Cell populations enriched either for CD3 T cells or for CDI4 and CD45 cells from three women with systemic sclerosis who had carried male fetuses (Patients 1, 18, and 23) contained Y-chromosome sequences (Table 1 and Fig. 2). No Y-chromosomepositive cells were detected in cell populations from these women that were depleted of CDI4 and CD45 cells or CD3 cells, nor in any of the cells from the two normal women or a woman with systemic sclerosis who had never been pregnant (Patient 17).

\section{Fluorescence in Situ Hybridization of Skin-Biopsy Specimens}

Nucleated cells containing Y chromosomes were detected in the skin-biopsy specimens of all seven women with systemic sclerosis whose specimens con-

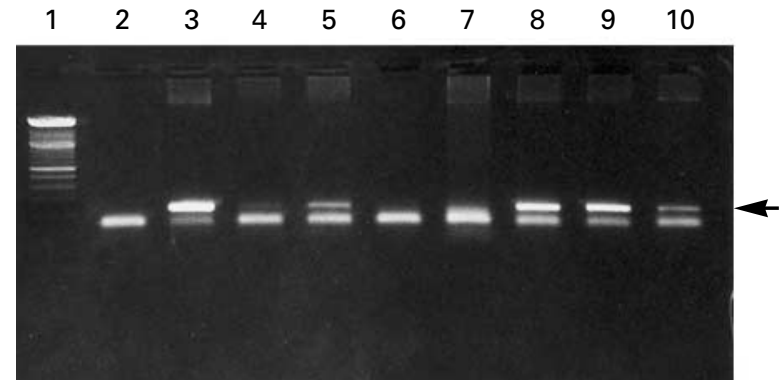

Figure 1. PCR Analysis of DYZ1 in DNA Extracted from Active Skin Lesions in Women with Systemic Sclerosis.

Lane 1 shows a 100 -bp size marker; lane 2 is blank; lane 3 shows DNA from a normal man; lane 4 shows DNA from $\mathrm{Pa}$ tient 5; lane 5 shows DNA from Patient 14; lane 6 shows DNA from Patient 15; lane 7 shows DNA from Patient 16; lane 8 shows DNA from Patient 4; lane 9 shows DNA from a normal man; and lane 10 shows DNA from Patient 2. The samples in lanes 3, 5, 8, 9, and 10 show a band corresponding to the 148bp product amplified from Y-chromosome DNA, as indicated by the arrow. The faster-migrating band in all lanes represents primer-dimer formation, as illustrated by its presence in lane 2, which contains no DNA (blank).

tained Y-chromosome sequences as detected by PCR and whose skin-biopsy specimens were tested by in situ hybridization. The majority of the Y-chromosome-containing nucleated cells were present within inflammatory-cell infiltrates localized in the extracellular matrix of the deep dermis (Fig. 3A) or in the walls of small vessels (Fig. 3B). Y-chromosome-containing nucleated cells were not seen in any of the skin biopsy specimens from the 10 normal women studied.

\section{Pregnancy History}

Among the 11 women with systemic sclerosis whose skin-biopsy specimens contained Y-chromosome-specific sequences detected by PCR amplification, all but 2 were known to have carried male fetuses (Table 2). Among the eight women with systemic sclerosis who had negative PCR skin-biopsy results, three (Patients 17, 19, and 20) had never been pregnant and had systemic sclerosis before the age of 20 years, one (Patient 21) had delivered two girls, and one (Patient 22) had delivered one girl. The remaining three women had died or were lost to follow-up. Of the 68 women with osteoarthritis or their relatives whose skin-biopsy specimens were examined, 30 percent were known to have had male offspring.

\section{DISCUSSION}

The results described here demonstrate the presence of fetal nucleated cells in the skin lesions of women with systemic sclerosis and thus support the hypothesis that persistent fetal cells in the maternal 
Table 1. Results of Fluorescence in Situ Hybridization of Magnetically Sorted Cells from Peripheral Blood of Two Normal Subjects and Four Patients with Systemic Sclerosis.

SUBJEcts

Pregnancy History*

Normal subjects $\ddagger$

Subject 1

Subject 2

Patients with systemic

sclerosis

Patient $1 \$$

Patient 17 I

Patient 18\|

Patient $23^{*}$
G0, P0

G0, P0

G2, P2 (both $\mathrm{M}$ )

G0, P0

Gl, P0 (M)
G3, P3 (2 M, l F)
No. of Y-Chromosome-Containing Cells Per 3000 Cells $†$

CD3 CD3-DEPLETED CD14 AND CD45 CD14- AND CD45-DEPLETED

${ }^{*} \mathrm{G}$ denotes number of pregnancies, $\mathrm{P}$ pregnancies carried to term, $\mathrm{M}$ male, and $\mathrm{F}$ female.

†CD3 denotes T cells, CD14 monocytes, CD45 leukocytes (these also contain CD3 cells), and ND not done.

‡These were normal women who had never been pregnant and whose age was similar to that of the women with systemic sclerosis.

\$Patient 1 was a 36-year-old woman who had a very rapid and progressive onset of systemic sclerosis within one year after the delivery of her second son.

IPatient 17 was a 15-year-old girl who had never been pregnant; her age at the onset of systemic sclerosis was 15 years.

||Patient 18 was a 41 -year-old woman with two sons in whom systemic sclerosis was diagnosed during her third pregnancy, which was with a female fetus.

**Patient 23 was a 39-year-old woman who had miscarried a male fetus.

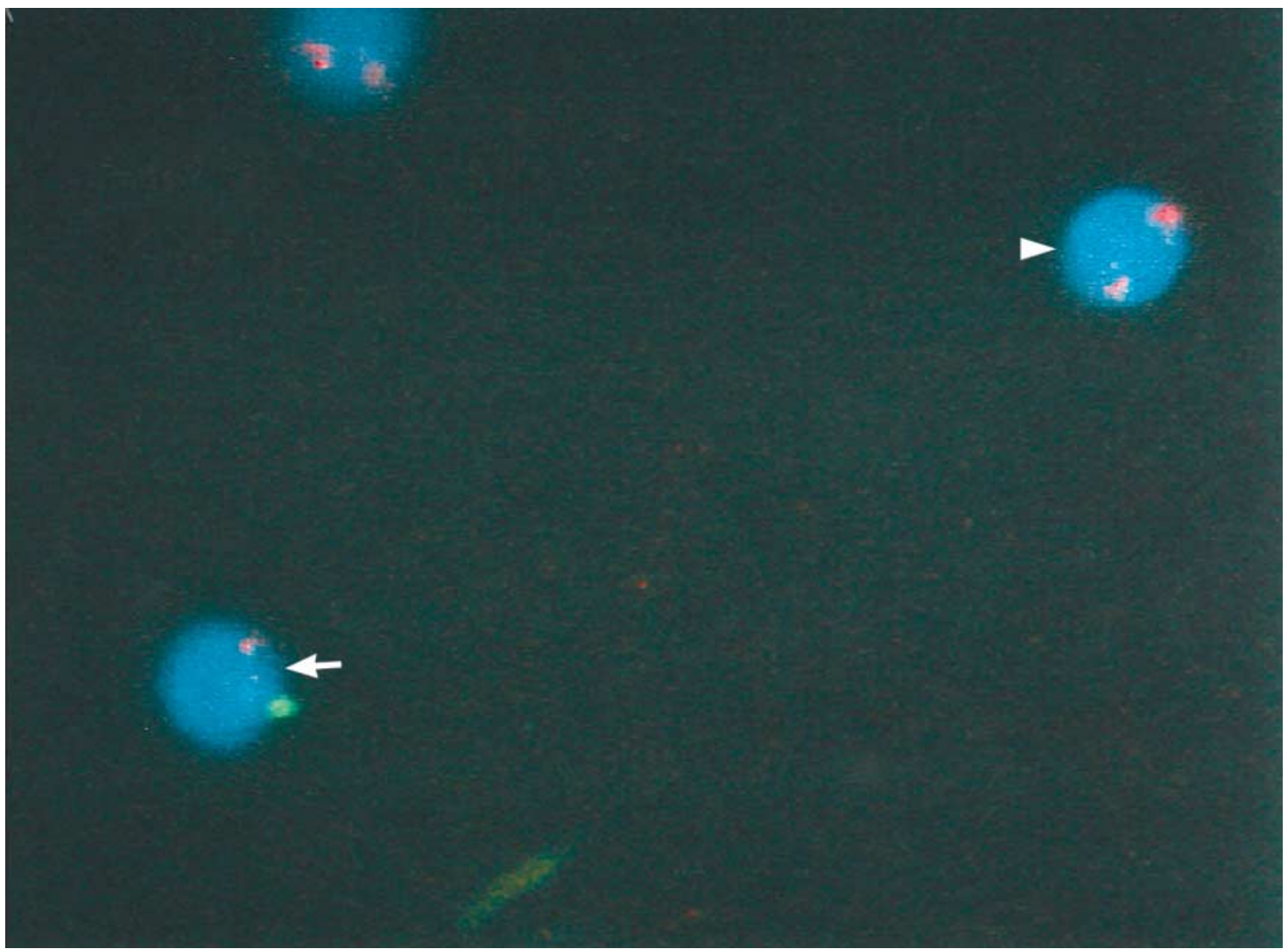

Figure 2. Fluorescence in Situ Hybridization of CD3 Cells from the Peripheral Blood of a Woman with Systemic Sclerosis.

The $\mathrm{X}$ chromosome was labeled with Texas red (red signal), and the $\mathrm{Y}$ chromosome with fluorescein (green signal). The nuclei are stained blue by 4,6-diamidino-2-phenylindole in an antifade solution (0.1 $\mu \mathrm{g}$ per milliliter) and viewed with an epi-fluorescence microscope with a triple-bandpass filter. The arrow indicates a nucleus containing both $\mathrm{X}$ and $\mathrm{Y}$ chromosomes, and the arrowhead indicates a nucleus with only an X chromosome. $(\times 2000$.) 


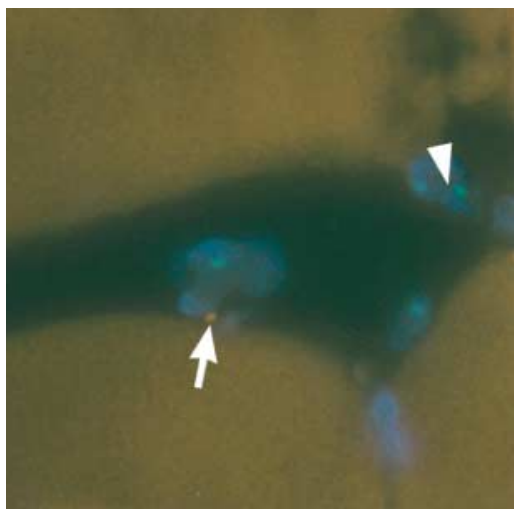

A

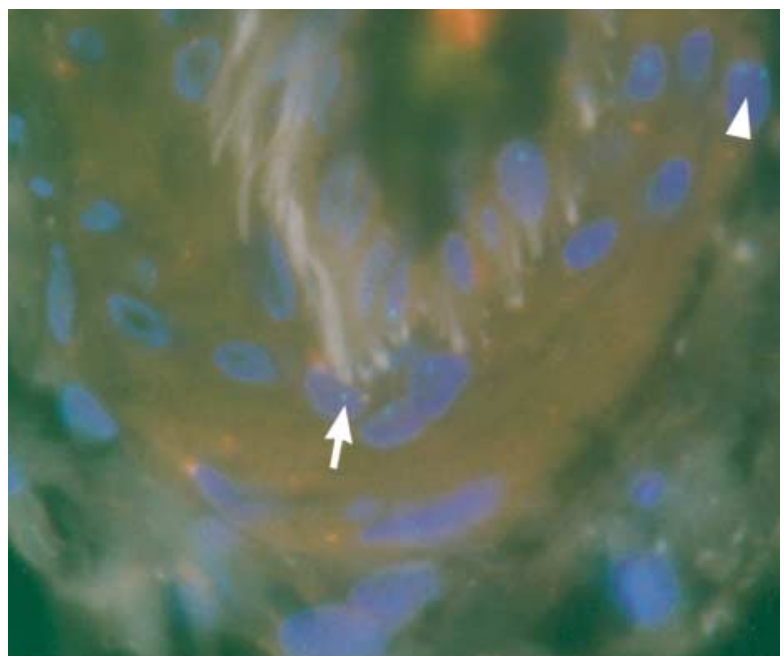

B

Figure 3. Fluorescence in Situ Hybridization of a ParaffinEmbedded Tissue Section from an Active Skin Lesion in a Woman with Systemic Sclerosis.

The $\mathrm{X}$ chromosome was labeled with fluorescein (green signal), and the $Y$ chromosome with Texas red (red signal). The sections were counterstained with 4,6-diamidino-2-phenylindole in an antifade solution ( $0.1 \mu \mathrm{g}$ per milliliter) and viewed with an epi-fluorescence microscope with a triple-bandpass filter. The nuclei are stained blue. In Panel $A(\times 1200)$, a nucleus with a $Y$ signal (red) is seen deep within the dermis (arrow). A nucleus containing two $X$ signals (green) is identified by an arrowhead. In Panel B $(\times 1200)$, a nucleus containing both $X$ (green) and $Y$ (red) signals is shown within the wall of a vessel (arrow). A nucleus containing two $X$ chromosomes (green signals) is identified by an arrowhead.

circulation or tissues mediate a graft-versus-host reaction, resulting in autoimmune disease. ${ }^{27-29}$

The fate of the cells transferred from the fetal to the maternal circulation (or vice versa) is not known, although transferred stem cells would be expected to mature either to relatively short-lived B cells or to longer-lived $\mathrm{T}$ cells. Thus, it is likely that the fetal cells in the skin lesions of women with systemic sclerosis are T cells. Although activated T cells have profound effects on fibroblast proliferation and biosyn-
Table 2. Pregnancy History and Onset of Systemic SClerosis in Women Positive for Y Chromosomes in DNA EXtracted from Biopsy Specimens of AfFected Skin.*

\begin{tabular}{|c|c|c|c|}
\hline $\begin{array}{l}\text { Patient } \\
\text { No. }\end{array}$ & $\begin{array}{l}\text { PREGNANCY } \\
\text { History }\end{array}$ & $\begin{array}{c}\text { Sex and Year of BiRTh of Children, } \\
\text { Miscarriage, or Termination } \\
\text { OF Pregnancy }\end{array}$ & $\begin{array}{l}\text { ONSET OF } \\
\text { DiseAse† }\end{array}$ \\
\hline 1 & G2, P2 & M 1987; M 1990 & 1991 \\
\hline 2 & $\mathrm{G} 4, \mathrm{P} 4$ & M 1956; M 1957; M 1959; F 1962 & 1991 \\
\hline 3 & G2, P2 & F 1964; M 1967 & 1991 \\
\hline 4 & G5, P4 & $\begin{array}{l}\text { F 1955; F 1956; M 1958; M 1966; } \\
\text { first-trimester miscarriage, sex } \\
\text { unknown, } 1968\end{array}$ & 1991 \\
\hline 5 & G3, P2 & $\begin{array}{l}\text { F 1980; F 1981; termination at } \\
3 \text { mo, sex unknown, } 1983\end{array}$ & 1990 \\
\hline 6 & G3, P3 & F 1956; M 1960; F 1963 & 1991 \\
\hline 7 & G5, P3 & $\begin{array}{l}\text { F 1956; miscarriage at } 3 \mathrm{mo} \text {, sex } \\
\text { unknown, 1957; F 1958; miscar- } \\
\text { riage at } 5 \mathrm{mo}, \mathrm{M}, 1960 ; \mathrm{F} 1963\end{array}$ & 1977 \\
\hline 8 & Gl, Pl & M 1956 & 1989 \\
\hline 9 & $\mathrm{G} 2, \mathrm{Pl}$ & $\begin{array}{l}\text { Termination at } 2 \text { mo, sex unknown, } \\
\quad 1988 ; \text { M } 1995\end{array}$ & 1989 \\
\hline 10 & G3, Pl & M 1965; F 1967; F 1970 & 1989 \\
\hline 11 & Unknown & Unknown & 1990 \\
\hline
\end{tabular}

${ }^{*} \mathrm{G}$ denotes number of pregnancies, $P$ pregnancies carried to term, $\mathrm{M}$ male, and $\mathrm{F}$ female.

†Onset of disease was determined by the appearance of clinically detectable cutaneous changes of systemic sclerosis.

thetic activity, there is no evidence that the foreign cells detected in the affected tissues of patients with systemic sclerosis are capable of stimulating the biosynthesis of connective tissue by resident fibroblasts.

It is likely that the hosts were immunologically unaware of the fetal cells, because the cells were not eliminated immunologically, as would have been expected. This tolerance of the fetal cells by the host may be due to maternal-fetal HLA compatibility. ${ }^{33}$ Tissues from women with the eosinophilia myalgia syndrome, eosinophilic fasciitis, or polymyositis did not contain Y-chromosome sequences; presumably, these women either had no male offspring or, if they did, fetal cells did not become localized in their tissues.

Passage of cells from the fetus to the mother is a frequent and expected occurrence, and passage of cells from the mother to the fetus also occurs. 22,34 Our study offers no explanation for the occurrence of systemic sclerosis in women who have not had children or in men. Maternal cells do reach the fetus, ${ }^{34}$ and if they persisted they could cause systemic sclerosis in women who have not had children or in men. Persistence of allogeneic $\mathrm{T}$ cells after blood transfusion may also explain the occurrence of systemic sclerosis in men or in nulliparous women. . $^{35,36}$

Our results indicate that the fetal cells that cross the placenta during pregnancy either remain in the circulation or migrate to various tissue sites. We hy- 
pothesize that a subsequent event, such as an environmental exposure (viral, chemical, or other), activates them, initiating a cascade of events that results in systemic sclerosis.

Supported by grants from the National Institutes of Health (AM19616, to Dr. Jimenez) and the Scleroderma Federation of the United States (to Dr. Artlett) and in part by a contract from the National Institute of Child Health and Human Development (CRMC-92-15, to Dr. Smith).

We are indebted to Drs. M.K. Haynes and R.J. Wapner for valued criticism of the manuscript and to Ms. A. Ruta, Ms. L. Gibbas, and Mr. K. Ansari for their expert technical assistance.

\section{REFERENCES}

1. Silman AJ, Black CM, Welsh KI. Epidemiology, demographics, genetics. In: Clements PJ, Furst DE, eds. Systemic sclerosis. Baltimore: Williams \& Wilkins, 1996:23-49.

2. Medsger TA Jr. Epidemiology of systemic sclerosis. Clin Dermatol 1994;12:207-16.

3. Silman AJ, Jannini S, Symmons D, Bacon P. An epidemiological study of scleroderma in the West Midlands. Br J Rheumatol 1988;27:286-90. 4. Steen VD, Medsger TA Jr. Epidemiology and natural history of systemic sclerosis. Rheum Dis Clin North Am 1990;16:1-10.

5. Medsger TA Jr, Masi AT. Epidemiology of systemic sclerosis (scleroderma). Ann Intern Med 1971;74:714-21.

6. Chosidow O, Bagot M, Vernant J-P, et al. Sclerodermatous chronic graft-versus-host disease: analysis of seven cases. J Am Acad Dermatol 1992;26:49-55.

7. Valenta LJ, Elias JN. Familial scleroderma in a kindred with high incidence of autoimmune disease: correlation with HLA-Al/B8 haplotype. Arch Dermatol 1987;123:1438-40.

8. Clements PJ, Furst DE, Ho W, Gale R. Progressive systemic sclerosislike disease following bone marrow transplantation. In: Black CM, Myer AR, eds. Current topics in rheumatology: systemic sclerosis (scleroderma). New York: Gower Medical Publishing, 1985:376-81

9. Graham-Brown RAC, Sarkany I. Scleroderma-like changes due to chronic graft-versus-host disease. Clin Exp Dermatol 1983;8:531-8.

10. Lawley TJ, Peck GL, Moutsopoulos HM, Gratwohl AA, Deisseroth $\mathrm{AB}$. Scleroderma, Sjogren-like syndrome, and chronic graft-versus-host disease. Ann Intern Med 1977;87:707-9.

11. Bos GMJ, Majoor GD, Slaaf DW, van der Gaar MJ, Weijmer-van Velzen JS, van Breda Vriesman PJ. Similarity of scleroderma-like skin lesions in allogeneic and syngeneic bone marrow transplantation models. Transplant Proc 1989;21:3262-3.

12. Herzog P, Clements PJ, Roberts NK, Furst DE, Johnson CE, Feig SA Progressive systemic sclerosis-like syndrome after bone marrow transplantation: clinical, immunologic, and pathologic findings. J Rheumatol 1980; 7:56-64.

13. Fleischmajer R, Perlish JS, Reeves JRT. Cellular infiltrates in scleroderma skin. Arthritis Rheum 1977;20:975-84.

14. Lambert IA, Suitters AJ, Janossy G, Thomas JA, Palmer S, Smith EG. Lymphoid infiltrates in skin in graft-versus-host disease. Lancet 1981;2: 1352 .
15. Jimenez SA. Cellular immune dysfunction and the pathogenesis of scleroderma. Semin Arthritis Rheum 1983;13:Suppl 1:104-13.

16. Fagundus DM, Leroy EC. Cytokines and systemic sclerosis. Clin Dermatol 1994:12:407-17.

17. Kahaleh MB, LeRoy EC. Interleukin-2 in scleroderma: correlation of serum level with extent of skin involvement and disease duration. Ann Intern Med 1989;110:446-50.

18. Postlethwaite $\mathrm{AE}$. Connective tissue metabolism including cytokines in scleroderma. Curr Opin Rheumatol 1993;5:766-72.

19. Janin-Mercier A, Devergie A, van Cauwenberg D, et al. Immunohistologic and ultrastructural study of the sclerotic skin in chronic graft-versus-host disease in man. Am J Pathol 1984;115:296-306.

20. Bell SA, Faust H, Mittermüller J, Kolb H-J, Meurer M. Specificity of antinuclear antibodies in scleroderma-like chronic graft-versus-host disease clinical correlation and histocompatibility locus antigen association. $\mathrm{Br} \mathrm{J}$ Dermatol 1996;134:848-54

21. O'Reilly RJ, Patterson JH, Bach FH, et al. Chimerism detected by HL-A typing. Transplantation 1973;15:505-7.

22. Bassukas ID. Is erythema toxicum neonatorum a mild self-limited acute cutaneous graft-versus-host-reaction from maternal-to-fetal lymphocyte transfer? Med Hypotheses 1992;38:334-8.

23. Schroder J. Transplacental passage of blood cells. J Med Genet 1975; $12: 230-42$.

24. Steele CD, Wapner RJ, Smith JB, Haynes MK, Jackson LG. Prenatal diagnosis using fetal cells isolated from maternal peripheral blood: a review. Clin Obstet Gynecol 1996;39:801-13.

25. Gill TJ III. Chimerism in humans. Transplant Proc 1977;9:1423-31 26. Bianchi DW, Zickwolf GK, Weil GJ, Sylvester S, DeMaria MA. Male fetal progenitor cells persist in maternal blood for as long as 27 years postpartum. Proc Natl Acad Sci U S A 1996;93:705-8.

27. Silman AJ, Black C. Increased incidence of spontaneous abortion and infertility in women with scleroderma before disease onset: a controlled study. Ann Rheum Dis 1988;47:441-4

28. Black CM, Stevens WM. Scleroderma. Rheum Dis Clin North Am 1989;15:193-212

29. Nelson JL. Maternal-fetal immunology and autoimmune disease: is some autoimmune disease auto-alloimmune or allo-autoimmune? Arthritis Rheum 1996;39:191-4.

30. Miller SA, Dykes DD, Polesky HF. A simple salting out procedure for extracting DNA from human nucleated cells. Nucleic Acids Res 1988;16: 1215

31. Subcommittee for Scleroderma Criteria of the American Rheumatism Association Diagnostic and Therapeutic Criteria Committee. Preliminary criteria for the classification of systemic sclerosis (scleroderma). Arthritis Rheum 1980;23:581-90.

32. Patri S, Daheron L, Kitzis A, Chomel J-C. Evaluation of bone marrow transplantation efficiency by competitive PCR on Y sequences. PCR Methods Appl 1994;3:361-4.

33. Artlett CM, Welsh KI, Black CM, Jimenez SA. Fetal-maternal $H L A$ compatibility confers susceptibility to systemic sclerosis. Immunogenetics 1997;47:17-22.

34. Appleton AL, Curtis A, Wilkes A, Cant AJ. Differentiation of maternofetal GVHD from Omenn's syndrome in pre-BMT patients with severe combined immunodeficiency. Bone Marrow Transplant 1994;14:157-9. 35. Brubaker DB. Immunopathogenic mechanisms of posttransfusion graft-vs-host disease. Proc Soc Exp Biol Med 1993;202:122-47.

36. Juji T, Takahashi K, Shibata Y, et al. Post-transfusion graft-versus-host disease in immunocompetent patients after cardiac surgery in Japan. N Engl J Med 1989;321:56 